\title{
Enhancement of Nodulation Efficiency of Mungbean Rhizobia
}

\author{
Ankit H. Patel ${ }^{{ }^{*}}$ and Lalit Mahatma ${ }^{2}$ \\ ${ }^{1}$ Department of Plant Molecular Biology and Biotechnology, Navsari Agricultural University, \\ Navsari-396 450, India \\ ${ }^{2}$ Department of Plant Pathology, Navsari Agricultural University, Navsari-396 450, India \\ *Corresponding author
}

\begin{tabular}{|c|c|}
\hline & A B S T R A C T \\
\hline $\begin{array}{l}\text { Rhizobium, } \\
\text { Naringenin, } \\
\text { Mungbean, } \\
\text { Enhancement. }\end{array}$ & \multirow{3}{*}{$\begin{array}{l}\text { Rhizobium-mungbean symbiosis was influenced by the rhizospheric } \\
\text { application of naringenin which increase nodule numbers. There was } \\
\text { significant improvement in the number of nodules in } 15 \mu \mathrm{M} \text { concentration } \\
\text { of naringenin over control, } 5 \mu \mathrm{M} \text { and } 10 \mu \mathrm{M} \text { concentration of naringenin. } \\
\text { Among the four different isolates of Rhizobia used, maximum nodulation } \\
\text { was observed in the isolate NAULN-1 in all the treatment including } \\
\text { control. Treatment with the isolate NAULN-1 and } 5 \mu \mathrm{M}, 10 \mu \mathrm{M} \text { and } 15 \mu \mathrm{M} \\
\text { concentration of naringenin concentration showed } 29,37 \text { and } 40 \text { numbers } \\
\text { of nodules over the } 29 \text { nodules in control treatment. Maximum no. of } \\
\text { nodules found in } 15 \mu \mathrm{M} \text { concentration of naringen in all the isolates. }\end{array}$} \\
\hline Article Info & \\
\hline $\begin{array}{l}\text { Accepted: } \\
\text { 23 September } 2017 \\
\text { Available Online: } \\
\text { 10 October } 2017\end{array}$ & \\
\hline
\end{tabular}

\section{Introduction}

The symbiosis between rhizobia and legumes is the result of millions of years of coevolution. Among the 19,000 species of legumes described so far, only a small proportion has been studied for their nodulation ability (Balachander et al., 2007).

For the establishment of an effective symbiosis two main classes of bacterial symbiosis genes are needed: nodulation and nitrogen fixation genes. Nodulation genes (e.g. nod $A B C$ ) encode enzymes responsible for the biosynthesis and secretion of Nod factors, which are host determinant lipochitooligosaccharides (LCOs) that interact with the plant flavonoids (Downie, 1998).
Nitrogen fixation genes (nif and fix) include the structural genes for the nitrogenase (nifHDK), the enzyme responsible for atmospheric nitrogen fixation (Kaminski et al., 1998).

The initial interaction between the host plant and free-living rhizobia is the release of a variety of chemicals by the root cells into the soil. Some of these encourage the growth of the bacterial population in the area around the roots (the rhizosphere). Nodule formation is controlled by extracellular bacterial signal molecules, called nod factors, which are recognized by the host plant (Lerouge et al., 1990; Schultze and Kondorosi, 1998). 
Flavonoids secreted by the root cells activate the nod genes in the bacteria which then induce nodule formation. The whole nodulation process is regulated by highly complex chemical communications between the plant and the bacteria.

Synthetic falvonoids are used as one of the soil amendment to improve the microclimate around the root zone. It can enhance the activities of the bacteria around it and result in the higher nodulation efficiency.

The natural flavonoids released from seeds and roots of plant cultivars limited nodulation. Adding flavonoids to the rhizosphere enhance nodulation and $\mathrm{N}_{2}$ fixation. Atmospheric biological nitrogen fixation by the rhizobium is directly proportionate to the number of effective nodule developed on root. Under the circumstances if the number of nodules is increased on the legume roots, they will certainly result in to the higher biological nitrogen fixation in a particular ecosystem.

\section{Materials and Methods}

\section{Collection of nodule samples}

Collection of nodule samples was collected from different mungbean growing villages of Navsari district. The plants were uprooted and fully developed pink colored nodules of desired size were selected carefully to collect the nodules. All the samples were collected at the early flowering stage i.e. from around 5060 days old crop.

\section{Isolation of Rhizobium Bacteria}

Intact nodules were surface sterilized, crushed in sterile distilled water and streaked on YEMA medium containing Congo red for isolation of Rhizobium bacteria. One colony from each location was selected as an isolate and tentatively named as NAULN-1, NAULM-2, NAULA-4 and NAULP-6 collected from NAU Farm, Maroli, Abrama and Pethan village of Navsari district respectively.

\section{Naringenin treatment}

Seeds of mungbean cultivar (Variety-GM-4) obtained from the Pulses Research Station, Navsari Agricultural University were treated with different isolates of rhizobium before sowing. The experiment was conducted based on Complete Randomized Design for layout. Naringenin (sigma) was applied to the soil at the time of sowing. Naringenin solution $5 \mu \mathrm{M}$, $10 \mu \mathrm{M}$ and $15 \mu \mathrm{M}$ prepared and applied to the different pot and one pot was kept without treatment as control. Plants from each different treated pot were uprooted on 45 days after sowing for observation of no of nodules.

\section{Results and Discussion}

Efficiency of Rhizobium-mungbean symbiosis was enhanced by the application of naringenin. To study the enhancement of nitrogen fixation ability through chemical agent, all the four bacterial isolates were used. Nodulation efficiency was tested by the pot method and applying $5 \mu \mathrm{M}, 10 \mu \mathrm{M}$ and $15 \mu \mathrm{M}$ concentration of naringenin.

Study of the data presented in table 1 and figure 1 indicated that among the four different isolates of Rhizobia used, maximum nodulation was observed in the isolate 1 in all the treatment including control. Total numbers of nodules were 29, 20, 18, and 24 respectively in the control in the isolates NAULN-1, NAULM-2, NAULA-4 and NAULP-6 respectively.

There was no significant difference in the control and $5 \mu \mathrm{M}$ concentration of naringenin in any of the treatment. There was significant improvements in the number of nodules in 10 $\mu \mathrm{M}$ concentration of naringenin over control and $5 \mu \mathrm{M}$ concentration of naringenin. 
Similarly there was significant improvement in the number of nodules in $15 \mu \mathrm{M}$ concentration of naringenin concentration over $10 \mu \mathrm{M}$ concentration of naringenin.

Treatment with the isolate NAULN-1 and 5 $\mu \mathrm{M}, 10 \mu \mathrm{M}$ and $15 \mu \mathrm{M}$ concentration of naringenin concentration showed 29, 37 and 40 numbers of nodules respectively.

Treatment with the isolate NAULM-2 and 5 $\mu \mathrm{M}, 10 \mu \mathrm{M}$ and $15 \mu \mathrm{M}$ concentration of naringenin concentration showed 22, 29 and 33 numbers of nodules respectively.

Fig.1 Pot Experiment (Naringenin treatment)
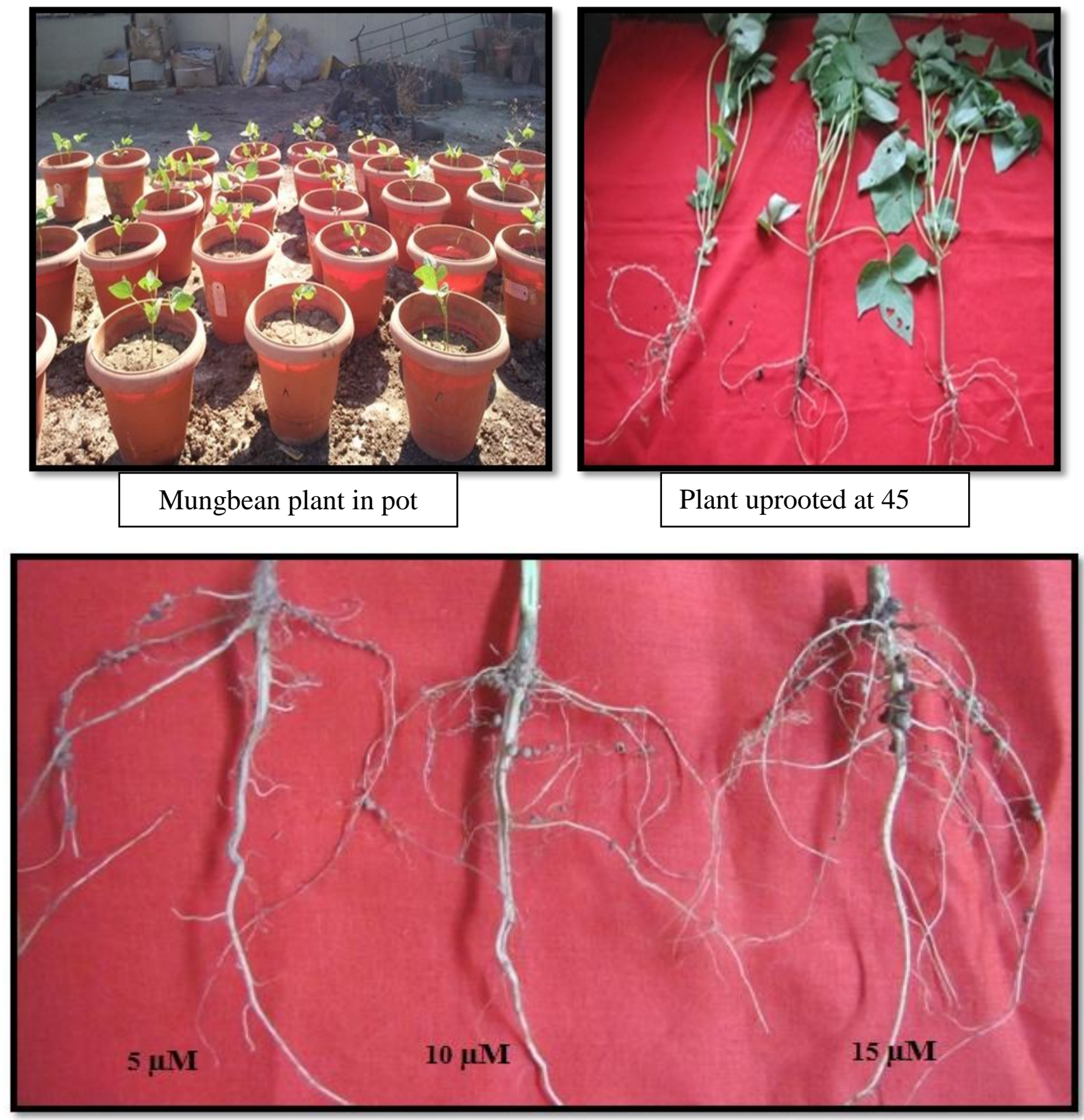

Nodulation observed in plant treated with NAULN-1 and $5 \mu \mathrm{M}, 10 \mu \mathrm{M}$ and $15 \mu \mathrm{M}$ Naringenin concentration 
Table.1 Effect of rhizosphere application of nod regulators (naringenin) on Enhancement of nodulation

\begin{tabular}{|c|c|c|c|c|c|}
\hline $\begin{array}{c}\text { Sr. } \\
\text { No. }\end{array}$ & $\begin{array}{c}\text { Naringenin } \\
\text { concentration }\end{array}$ & $\begin{array}{c}\text { No. of Nodules } \\
\text { formed by } \\
\text { NAULN-1 }\end{array}$ & $\begin{array}{c}\text { No. of Nodules } \\
\text { formed by } \\
\text { NAULM-2 }\end{array}$ & $\begin{array}{c}\text { No. of Nodules } \\
\text { formed by } \\
\text { NAULA-4 }\end{array}$ & $\begin{array}{c}\text { No. of Nodules } \\
\text { formed by } \\
\text { NAULP-6 }\end{array}$ \\
\hline $\mathbf{1}$ & $\mathbf{5} \boldsymbol{\mu M}$ & 29 & 22 & 20 & 22 \\
\hline $\mathbf{2}$ & $\mathbf{1 0} \boldsymbol{\mu M}$ & 37 & 29 & 27 & 30 \\
\hline $\mathbf{3}$ & $\mathbf{1 5} \boldsymbol{\mu M}$ & 40 & 33 & 29 & 34 \\
\hline $\mathbf{4}$ & Control (No Nar) & 29 & 20 & 18 & 24 \\
\hline $\mathbf{5}$ & $\mathbf{C D}$ & 1.988 & 1.540 & 1.406 & 1.540 \\
\hline $\mathbf{6}$ & $\mathbf{C V}$ & 3.825 & 3.846 & 3.884 & 3.636 \\
\hline $\mathbf{7}$ & SEm & 0.645 & 0.500 & 0.456 & 0.500 \\
\hline
\end{tabular}

Treatment with the isolate NAULA-4 and 5 $\mu \mathrm{M}, 10 \mu \mathrm{M}$ and $15 \mu \mathrm{M}$ concentration of naringenin concentration showed 20, 27 and 29 numbers of nodules respectively. Enhancement of nodulation per treatment with the isolate NAULP-6 and $5 \mu \mathrm{M}, 10 \mu \mathrm{M}$ and $15 \mu \mathrm{M}$ concentration of naringenin concentration showed 22,30, 34 numbers of nodules respectively.

Results were in accordance with addition of $10 \mu \mathrm{M}$ luteolin (Kapulnik et al., 1987) and naringenin (Jain et al., 1990) to the rhizosphere of alfalfa seedlings increased nodulation. Naringenin which is known to be an inducer of nod genes of Rhizobium leguminosarum (Zaat et al., 1987). Flavonoids present in root exudates of legumes are known to induce the expression of nod genes (Peters et al., 1986). Host controlled flavone limitations to root nodulation is known in alfalfa (Kapulnik et al., 1987). The increase in symbiotic efficiency observed in the present investigation was perhaps due to the effect of naringenin on nod genes of Rhizobium.

From this investigation it is fact that nodulation has been enhanced by the application of naringenin opens up another technology for maximizing symbiotic nitrogen fixation.

\section{References}

Balachandar, D., Raja, P.; Kumar K. and Sundaram S. 2007. Non-rhizobial nodulation in legumes. Biotechnol. and Mol. Biol. Review, 2 (2): 49-57.

Downie, J.A., 1998. Functions of rhizobial nodulation genes. In The Rhizobiaceae (Eds.) H. P. Spaink, A. Kondorosi, and P. J. J. Hooykaas Dordrecht, The Netherlands: Kluwer Academic Publishers, pp 387-402.

Jain, V., Garg, N. and Nainawatee, H. S. 1990. Naringenin enhanced efficiency of Rhizobium meliloti -alfalfa symbiosis. World J. Microbiol. Biotechnol; 6(4): 434-436.

Kaminski, P. A., Batut, J. and Boistard, P. 1998. A survey of symbiotic nitrogen fixation by rhizobia, In: The rhizobiaceae molecular biology of model plant-associated bacteria (Eds.) H. P. Spaink, A. Kondorosi, and P. J. J. Hooykaas, Kluwer Academic Publishers, Dordrecht, pp 432-460.

Kapulnik, Y., Joseph, C. M. and Phillips, D. 1987. Flavone limitations to root nodulation and symbiotic nitrogen fixation in alfalfa. Plant Physiol., 84: 1193-1196.

Lerouge, P., Roche, P., Faucher, C., Maillet, F., Truchet, G., Prome, J. C. and 
Denarie, J. 1990. Symbiotic hostspecificity of Rhzobium meliloti is determined by a sulphated and acylated glucosamine oligosaccharide signal. Nature, 344: 781-784.

Peters, N. K., Frost, J. W. and Long, S. R. 1986. A plant flavone luteolin induces expression of Rhizobium meliloti nodulation genes. Science, 233: 977980.

Schultze, M., and Kondorosi, A. 1998.
Regulation of symbiotic root nodule development. Аnnu. Rev. Genet., 32: 33-57.

Zaat, S. A. J., Vanbrussel, A. A. N., Tak, T., Pees, E. and Lugtenberg, B. J. J. 1987. Flavonoids induce Rhizobium leguminosarum to produce nod $A B C$ gene related factors that cause thick short roots and root hair responses on Common Vetch. J. Bacteriol. 169: 3388-3391.

\section{How to cite this article:}

Ankit H. Patel and Lalit Mahatma. 2017. Enhancement of Nodulation Efficiency of Mungbean Rhizobia. Int.J.Curr.Microbiol.App.Sci. 6(10): 2581-2585. doi: https://doi.org/10.20546/ijcmas.2017.610.303 